\title{
Implication of anthropometric profile and alimentary consumption on risk for diseases among school children in the $1^{\text {st }}$ to $4^{\text {th }}$ grades
}

\author{
Vanessa Monteiro', Graciette Matioli2," \\ ${ }^{1}$ Center for Health Sciences, State University of Maringá, ${ }^{2}$ Pharmacy Department, State University of Maringá
}

\begin{abstract}
This study aimed to determine the anthropometric profile and diet of 652 school children from the $1^{\text {st }}$ to $4^{\text {th }}$ grades of elementary education in six private schools in the city of Maringá, Paraná, Brazil. Children's weight and height were classified according to the Body Mass Index proposed by Must et al. (1991). Food consumption was evaluated by means of a questionnaire about daily food frequency. Statistical analysis was carried out using linear and logistic regression tests, with a significance level of $5 \%$. High rates of overweight and obesity, $21.9 \%$ and $13.3 \%$ respectively, were observed, which did not show a significant relationship with total food consumption. The data obtained were: high consumption of foods rich in energy, such as sugar- and fat-rich foods, and insufficient consumption of low-energy foods that are sources of micronutrients, such as vegetables. It is necessary to enhance the promotion of good alimentary and health habits within schools to lower risk factors for developing diseases, as well as to develop and validate a questionnaire to reliably assess the diet of the infant population.
\end{abstract}

Uniterms: Alimentary habits. Obesity. Body mass index. Infant nutrition.

Este trabalho objetivou determinar o perfil antropométrico e o consumo alimentar entre escolares de $1^{\mathrm{a}}$ a $4^{\mathrm{a}}$ séries do ensino fundamental de escolas privadas de Maringá - PR. A amostra de estudo foi de 652 alunos. Verificou-se o peso e a estatura e classificados de acordo com o Índice de Massa Corporal proposto por Must et al. (1991). O consumo alimentar foi avaliado por meio de um questionário de freqüência alimentar diária. A análise estatística foi realizada pelos testes de associação e regressão logística linear, com nível de significância de 5\%. Verificaram-se índices altos de sobrepeso e obesidade, $21,9 \%$ e $13,3 \%$, respectivamente, os quais não mostraram relação significativa com o consumo alimentar. Os dados obtidos foram: alto consumo de alimentos ricos em energia, como aqueles ricos em açúcares e gorduras, e um consumo insuficiente de alimentos pouco energéticos e fonte de micronutrientes, como os vegetais. Para diminuir os fatores de risco do desenvolvimento de doenças faz-se necessário o aumento da promoção de bons hábitos alimentares e saúde dentro das escolas, além da necessidade de elaborar e validar um questionário de consumo alimentar para avaliar a população infantil.

Unitermos: Hábitos alimentares. Obesidade. Índice de massa corporal. Nutrição infantil.

\section{INTRODUCTION}

The first years of life are decisive for the growth of children as they mark a period of particular vulnerability (Silva et al., 2000; Modesto et al., 2007). The formation of feeding habits occurs through the consumption frequency of certain foods, starting from the first year of life, creating demands of taste and involving strong regional influences

\footnotetext{
*Correspondence: G. Matioli. Departamento de Farmácia, Universidade Estadual de Maringá. Av. Colombo, 5790 Bloco PØ2, 87020-900 - Maringá - PR, Brazil.Email: gmatioli@uem.br
}

and affective memories related to the family and to the social environment (Gouveia, 1999; Mondini et al., 2007).

Alimentary deficiencies in children lead to stunted growth and increased vulnerability to infections, and promote deficiencies in the maturation process of the nervous system and in mental and intellectual development, provoking morphological and functional imbalances which, depending on intensity and duration, may be irreversible (Rottemberg, Vargas, 2004).

Obesity can lead to serious repercussion for health, causing diseases such as mellitus diabetes, hypertension, orthopedic muscular lesions, cardiovascular diseases and 
certain types of cancer, as well as skin problems, spots and wrinkles, and diseases that result in greater morbidity and reduced longevity in adult life (Mendes et al., 2006; Rocca et al., 2008; Ricardo et al., 2009). According to recent estimates, $20 \%$ of school-age children in Europe are carrying excess body fat (with a quarter of these being obese), where this poses an increasing risk of this group developing chronic diseases with a significant likelihood of some individuals having multiple risk factors for cardiovascular diseases, Type 2 diabetes and other co-morbidities before or during early adulthood (Matthews, 2007).

Data on the prevalence of obesity in Brazil remains scant. Studies involving the diagnosis of obesity, for the most part, use samples that are not representative of the country, but of specific groups or age ranges. The precocious diagnosis of overweight and obesity is of great importance for public health, because treatment in this initial phase of life can be more effective and less costly to the State, given the risk of persistent obesity in adulthood and its association with several morbid conditions (Bueno, Marchioni, Fisberg, 2003). In 2001, there were around three million obese children in Brazil under the age of 10 years (Corso et al., 2001).

Studies of prevalence of overweight and obesity in children and adolescents from different socioeconomic backgrounds have been conducted. The highest prevalence found in children studying in private school and in children studying in schools located in the best zone of the city, reflects the significance of the association between highest socioeconomic levels and excess weight (Silva, Balaban, Motta, 2005).

Whereas school-age children go through changes in the way they interact with their classmates and family, interfering directly in their feeding, and considering that more studies with students of public school than private school have been carried out to date, this study aimed to determine the anthropometric profile and food consumption of students in the $1^{\text {st }}$ to $4^{\text {th }}$ grades of private elementary schools in Maringá, Paraná in 2005.

\section{METHOD}

A transversal study, with a 5\% level of significance, was carried out involving school children in the $1^{\text {st }}$ to $4^{\text {th }}$ grades of elementary education (between 6 and 11 years old) at six private schools in the municipal district of Maringá, Paraná. All 25 private schools in the municipal district of Maringá that had students enrolled in the $1^{\text {st }}$ to $4^{\text {th }}$ grades were contacted, but only six schools, with similar characteristics, agreed to participate in this study. The decision to use private schools was made according to the probability that the students of these institutions would have greater access to ready-made and commercially manufactured foods, as well as to fast-food chains. The total number of students in the $1^{\text {st }}$ to $4^{\text {th }}$ grades enrolled at these institutions was 1,152 . The total population of the study was 652 students, all of whom participated voluntarily, and whose parents or guardians had signed the free term of consent permitting them to participate. The remaining students did not participate because their parents did not allow it or because they did not sign the free term of consent.

The study was carried out in the period spanning from February to June 2005, and had been previously approved by the Ethics Committee of the State University of Maringá (SUM).

Anthropometric profiles were determined by measuring the weight and height of the students. Height was measured in the children without shoes, with their feet placed together and heels against the wall, to which a metric tape with a scale in millimeters had been affixed. The students were made to stand erect and face forwards without inclining their heads. A measuring square was placed flat on the top of the students' heads. Their height was recorded according to the $0.5 \mathrm{~cm}$ division nearest to the $90^{\circ}$ angle formed between the square and the wall (Jelliffe, 1968).

Weight was measured using a digital balance (Plenna) with a capacity of up to $130 \mathrm{Kg}$ and a sensitivity of $100 \mathrm{~g}$. Weight was gauged in the students without shoes and wearing light clothing (Jelliffe, 1968). The data was always collected by the same operator and with the equipment properly adjusted and calibrated.

After measuring height and weight, the students were classified into four different groups according to the calculation of their Body Mass Index (BMI). Students that had a BMI below the $20^{\text {th }}$ percentile were classified as underweight and those with a BMI between the $20^{\text {th }}$ and $85^{\text {th }}$ percentiles, as eutrophic. Students with a BMI between the $85^{\text {th }}$ and $95^{\text {th }}$ percentiles were classified as overweight and those with a BMI above the $95^{\text {th }}$ percentile were classified as obese (Must, Dallel, Dietz, 1991).

The method used to evaluate food consumption was a questionnaire about food frequency, the most commonly used technique for the verification of feeding habits from a qualitative point of view (Willett, 1994). The foods selected were divided into eight groups: cereals, vegetables, fruit, meat, beans, milk and derivatives, sugars, and fats (Cruz, Phillippi, 2003).

Each food group contained the most commonly encountered and used foods in Brazil. The cereal group contained foods such as rice, bread, cookies and pastas. The vegetable group was divided into leafy vegetables and 
legumes. The fruit group contained foods such as apple and banana and similar items. The meat group was divided into beef, pork, fish and fowl. The bean group contained common beans (Phaseolus vulgaris) and other items. The milk group consisted of items such as milk, cheese, cheese curds and yogurt. The sugar group contained candies, chewing gum, chocolate, confectionary in general and soft drinks. The last group, fats, contained margarine, oil, mayonnaise and commercially produced savory snacks.

Each student answered the questionnaire orally and individually, and all students were evaluated by the same researcher. Students were asked if they had consumed all foods in each of the food groups. When there was a positive response, the student was asked how many times a day they consumed the food in question.

The classification as to whether food consumption was ideal or not was made according to the most recent alimentary recommendations in previously published literature, which included a large number of food groups for children (Gouveia, 1999; Cruz, Phillippi, 2003). Each food group has a given recommended number of times it should be consumed per day. For the cereal group, the ideal consumption is between four and six times a day. For the vegetable and milk-and-derivatives groups, consumption of any of the foods was recommended two to three times a day. For the fruit group, the recommended consumption is at least once, and up to three times a day. For the other groups (beans, sugars and fats), the recommended consumption is no more than twice a day (Cruz, Phillippi, 2003).

The classification of food consumption began by summing the number of times a day each food was consumed in order to determine the daily consumption of each food group. From this data, food consumption was classified into three ratings: low consumption, normal consumption and excessive consumption. Low consumption was determined as being when there was no consumption or a lower than the minimum recommended consumption for each group. Normal consumption was determined as being when the consumption for each food group was between the minimum and maximum recommended levels. Excessive consumption was determined as being when a student consumed a food more times or many more times than the maximum daily recommendation.

Linear and logistic regression tests were conducted for the statistical analysis of the data.

\section{RESULTS}

Table I summarizes the gender and age distribution of the students in each school studied. It can be seen that there was a slight predominance of females $(52 \%)$ compared to males (48\%).

Table II shows the BMI and gender of the studied population. Greater rates of underweight and overweight students are evident for females, although a greater rate of obesity was found in males. The results of the Chi-squared test indicated that there was a statistically significant association between females and underweight based on BMI $(p=0.004)$. Table II also shows a relationship between BMI and student age. A significant relationship can be seen between underweight and age less than or equal to seven years.

Table III summarizes the relationship between food consumption and the prevalence of overweight and obese students. The Odds Ratio (OR) values found rule out the possibility that students with normal weight become obese through the food consumption errors studied, as the values found were not significant in terms of identifying a direct relationship between feeding and obesity. However, in this study, very similar feeding errors were found between obese and eutrophic children, with no direct relationship between feeding and the prevalence of obesity being identified with respect to the quality of food, since this was a qualitative study with food frequency reported in an interview.

Figure 1 shows food frequency consumption by food group. A high consumption of very energetic foods, such

TABLE I - Distribution of number and percentage of school children according to age and gender in schools studied (n-652). Maringá - PR, 2005

\begin{tabular}{lccccccc}
\hline Characteristic & School A & School B & School C & School D & School E & School F & Total \% \\
\hline Age & & & & & & & \\
$\quad \leq 7$ years & 26 & 39 & 65 & 23 & 27 & 46 & 34.7 \\
$\quad \begin{array}{l}\text { 8 years } \\
\text { Gender }\end{array}$ & 67 & 73 & 97 & 43 & 83 & 63 & 65.3 \\
$\quad$ Female & 55 & 64 & 92 & 28 & 53 & 48 & 52.2 \\
$\quad$ Male & 38 & 48 & 70 & 38 & 57 & 61 & 47.8 \\
\hline
\end{tabular}


TABLE II - Distribution of number and percentage of school children according to gender and age and values associated to BMI indices. Maringá - PR, 2005

\begin{tabular}{|c|c|c|c|c|c|c|c|c|}
\hline \multirow[t]{2}{*}{ BMI } & \multicolumn{2}{|c|}{ Gender } & \multirow{2}{*}{$\begin{array}{c}\text { Relative Risk } \\
(\mathrm{CI}=95 \%)\end{array}$} & \multirow[t]{2}{*}{$p$-value } & \multicolumn{2}{|c|}{ Age } & \multirow{2}{*}{$\begin{array}{l}\text { Relative Risk } \\
(\mathrm{CI}=95 \%)\end{array}$} & \multirow[t]{2}{*}{$p$-value } \\
\hline & Female & Male & & & $\leq 7$ years & $\geq 8$ years & & \\
\hline Underweight & $28(4.3 \%)$ & $8(1.2 \%)$ & 3.01 & 0.004 & $21(3.2 \%)$ & $15(2.3 \%)$ & 2.41 & 0.0005 \\
\hline Eutrophic & $199(30.5 \%)$ & $187(28.7 \%)$ & 1 & & $134(20.6 \%)$ & $252(38.7 \%)$ & 1 & \\
\hline Overweight & 77 (11.8\%) & $66(10.1 \%)$ & 1.07 & 0.710 & $34(5.2 \%)$ & $109(16.7 \%)$ & 0.67 & 0.217 \\
\hline Eutrophic & 199 & 187 & 1 & & 134 & 252 & 1 & \\
\hline Obese & $36(5.5 \%)$ & $51(7.8 \%)$ & 0.71 & 0.110 & $37(5.7 \%)$ & $50(7.6 \%)$ & 1.31 & 0.2124 \\
\hline Eutrophic & 199 & 187 & 1 & & 134 & 252 & 1 & \\
\hline
\end{tabular}

as those in the sugar and fat groups (68.6\% and 58.5\%, respectively), can be seen. On the other hand, low-calorie more-nutritious foods, such as those in the vegetable and milk and derivatives groups, showed lower-than-ideal consumption. For example, $91.1 \%$ of students did not consume, or consumed little, vegetables. In the milk group, $64.9 \%$ of the students consumed either insufficient quantities or did not consume items from this group.

Figure 2 shows a comparison of the anthropometric profiles of the students from the six schools. It can be seen that rates of underweight and malnutrition were low across all the schools, thereby presenting low rates of health risk for these students. With regard to eutrophy, more than half of the students had normal weight across all of the schools, with schools A, B and F having more than $60 \%$ with ideal weight.

With regard to overweight students, high rates were found in all the schools, with the highest rates being observed in schools C, D and E, where more than $20 \%$ of the students were overweight to some degree. Obesity was also found to be high in all of the schools, with an especially high rate being observed in school $\mathrm{F}$.

\section{DISCUSSION}

In Table I, the population was characterized according to age and sex. It can be seen that in all the schools there was a high number of students aged greater than or equal to 8 years, totaling $65.3 \%$ of the study population. With regard to gender, there was a slight predominance of girls $(52.2 \%)$ compared to boys $(47.8 \%)$.

In this study, rates of $21.9 \%$ and $13.3 \%$ were found for overweight and obese students, respectively; rates that are very high compared to World Health Organization (WHO) recommendations (WHO, 1998), which indicate a normal obesity rate of $2.3 \%$ of the total population. However, the data found on the rates of overweight and obese school children in Maringá are very similar to data reported in
TABLE III - Relationship between excessive consumption of food and overweight and obesity

\begin{tabular}{lcc}
\hline Food Group & $\begin{array}{c}\text { Estimate } \\
(\mathbf{C I}=\mathbf{9 5 \%})\end{array}$ & $\boldsymbol{p}$-value \\
\hline Overweight & & \\
$\quad$ Milk and derivatives & 1.51 & 0.09 \\
$\quad$ Sugars & 1.20 & 0.51 \\
$\quad$ Fats & 1.21 & 0.94 \\
Obesity & & \\
$\quad$ Milk and derivatives & 1.25 & 0.64 \\
$\quad$ Sugars & 1.04 & 0.88 \\
$\quad$ Fats & 1.08 & 0.74 \\
\hline
\end{tabular}

previous literature in recent years, For example, a study evaluating 4,964 children between six and ten years of age from 345 elementary schools was conducted in the state of Santa Catarina. Body mass index was used to diagnose overweight and obesity and $52.2 \%$ of the students were female. The prevalence of overweight and obesity were $15.4 \%$ and $6.0 \%$ and no association between overweight or obesity was found for gender or age (Ricardo et al., 2009).

Despite the fact that no statistically significant evidence was found in the sample that directly relates gender to BMI, a greater rate of overweight was observed in females $(11.8 \%)$ compared to males $(10.1 \%)$. However, regarding obesity, males showed a higher rate $(7.8 \%)$ than females $(5.5 \%)$ (Table I). This data corroborates the findings of other studies in Brazil. In a study carried out in the city of São Paulo, 2,519 students from the $1^{\text {st }}$ and $2^{\text {nd }}$ grades were evaluated based on three diagnostic anthropometric criteria. The results indicated rates of overweight in girls and boys of $13.83 \%$ and $10.29 \%$, respectively. Rates of obesity were $16.50 \%$ for girls and $13.67 \%$ for boys (Sotelo, Colugnati, Taddei, 2004). Another study carried out in the city of Rio de Janeiro (Anjos et al., 2003) reported rates of overweight and obesity in girls of $17.2 \%$ 

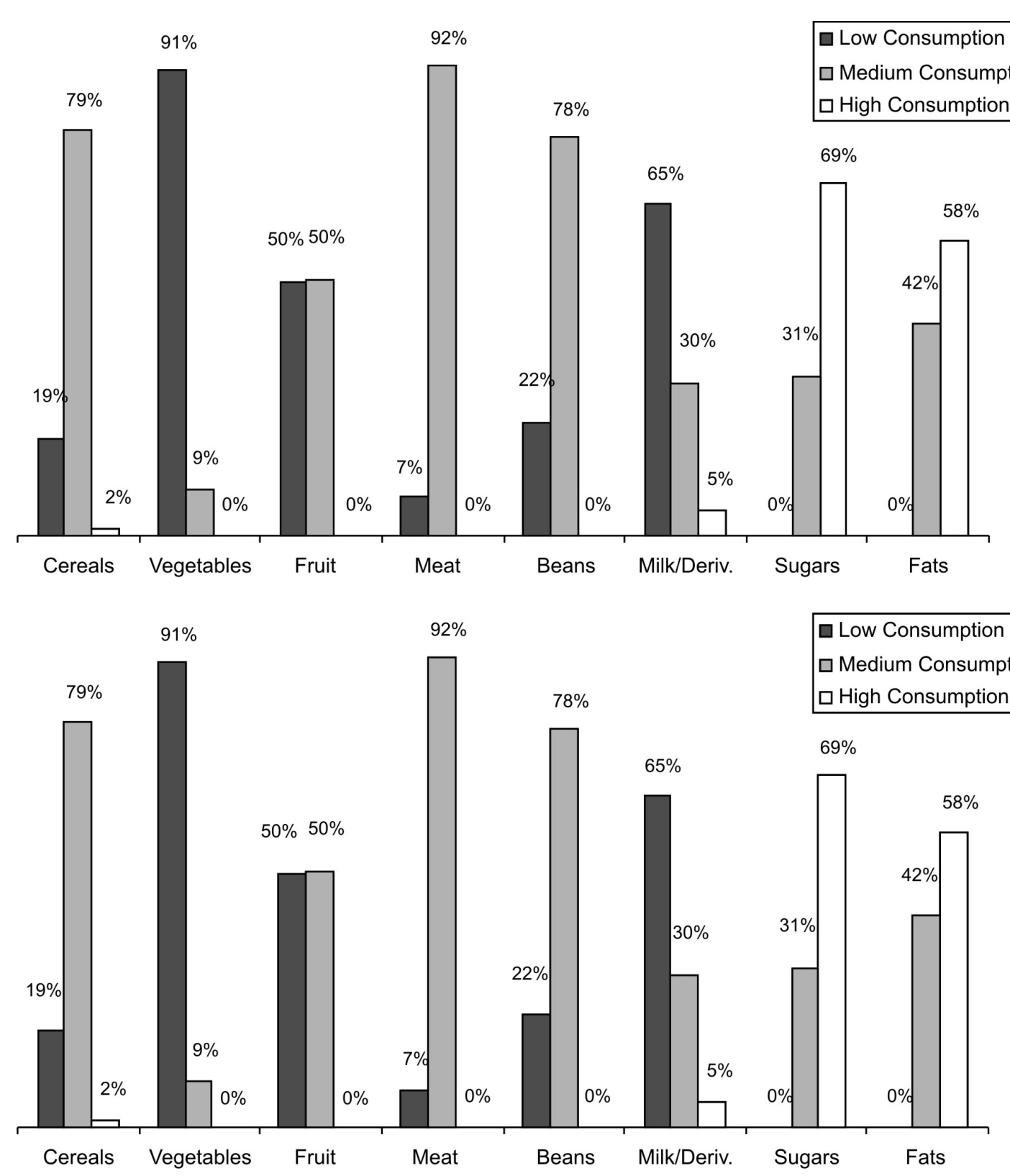

FIGURE 1 - Distribution of percentage of children according to consumption of food groups. Maringá - PR, 2005.

and $5.2 \%$, and in boys of $15 \%$ and $5.3 \%$, respectively, within a population of 3,430 students between seven and ten years old. It should be noted, however, that this study used a different method for classifying the anthropometric profile of the students, which may account for the greater difference between the rates found by these authors and those found in the present study.

In 2005, another study evaluated 573 school children between the ages of eight and ten in Rio Grande do Sul. Using the same methods as the present study, rates of overweight boys and girls were $17.3 \%$ and $16.6 \%$, respectively. Rates of obesity were $7.4 \%$ for boys and $7.6 \%$ for girls (Triches, Giugliane, 2005).
Despite there being variability in the results found in the studies that relate weight to gender, in the majority of the literature there was a greater prevalence of overweight girls. The present study confirms the data found in this respect. However, in contrast to the majority of previous literature, this study showed a higher rate of obesity in boys.

On the other hand, there were higher rates of underweight girls compared to boys $(\mathrm{RR}=3.01)$. This may have occurred because girls are more concerned with their appearance, especially when starting school, when the comparisons between slim and fat children are inevitable (Gouveia, 1999). For the whole population of the study, the 

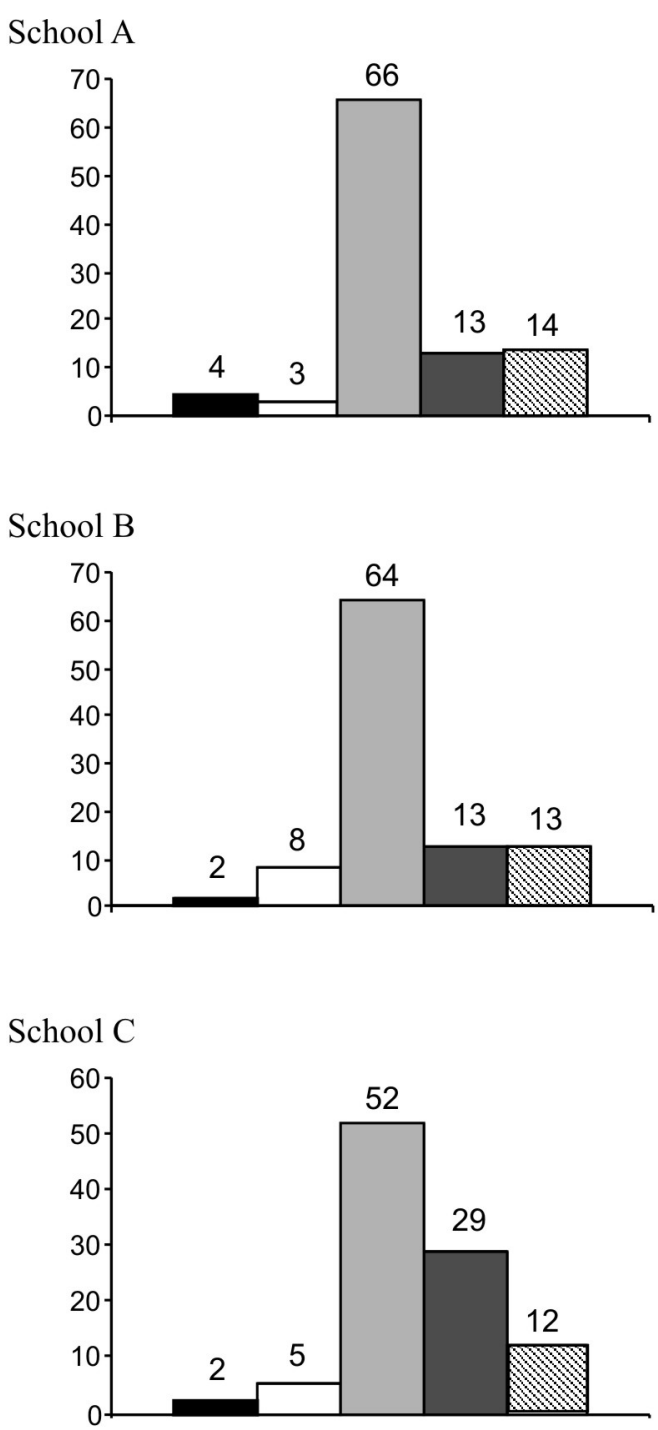

School D

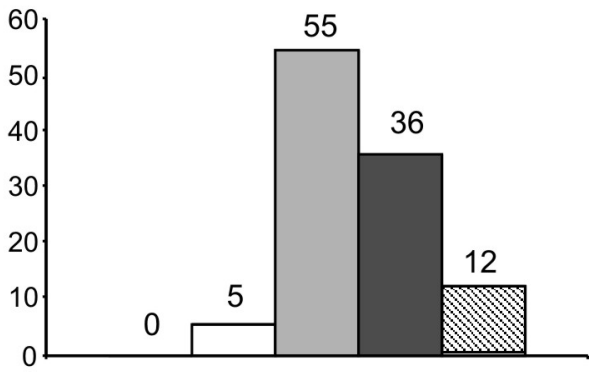

School E

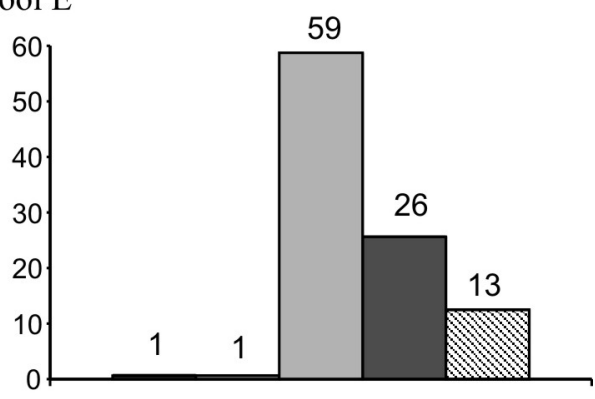

School F

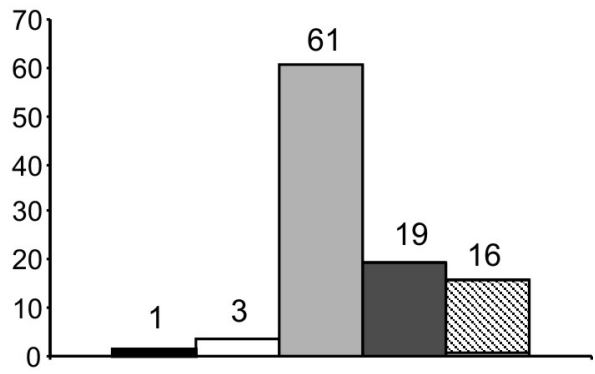

Malnourished $\square$ Underweight $\square$ Eutrophic

Overweight Obese

FIGURE 2 - Distribution of percentage of children of different schools according to indices of nutritional classification. Maringá $-\mathrm{PR}, 2005$.

overall rate of underweight children was $5.5 \%$, confirming data found in Brazil by other authors, describing rates from 3 to $20 \%$ of the infant population (Sotelo, Colugnati, Taddei, 2004; Conde, Monteiro, 2000).

Another interesting aspect of this study was the data related to the BMI and age of the students. Statistically significant data was found in relation to underweight in children less than seven years old $(\mathrm{RR}=2.41)$, a phase in which the child is adapting to school life and accumulating new habits, including feeding habits.

For overweight children, the rates found varied from $5.2 \%$ for those less than or equal to seven years old and $16.7 \%$ for those greater than or equal to eight years. Despite the fact that a direct statistical relationship between overweight and the age of the students was not found in this study, the data suggests that children of ages up to seven years have a protective factor against obesity compared to children over eight years of age, probably due to feeding habits that are still strongly linked to the family and under the supervision of the parents. Mondini et al. (2007) assessed the prevalence of overweight in public school first graders and the association between overweight and socio-environmental factors in a city in Greater Metropolitan São Paulo, Brazil. The family environment has a strong influence on overweight in children embarking on first grade in public schools because the factors associated with overweight were: mother's obesity, high consumption of junk food, more than 4 hours a day 
watching TV, and daily household per capita availability of vegetable oil (around 3 tablespoons).

With regard to obesity, there was no relative risk indicating a relationship between age and BMI, but the rates found varied from $5.7 \%$ for children less than or equal to seven years and $7.6 \%$ for children greater than or equal to eight years.

This set of data confirms various aspects of infant feeding habits reported by many authors. Children of pre-school age (5 to 6 years) still maintain the feeding habits inherited from their parents and are influenced almost exclusively by the family. As the child grows, their world expands and their social contacts acquire greater importance. The elementary school phase starts at seven years and ends in pre-adolescence. In this phase, the influence of classmates increases and the child becomes better able to choose what they want to eat, preferring to get snack food from the school than taking food from the house, and have general access to soft drinks and sweets, which can cause bad feeding habits and an increase in overweight and obesity in this age range. Therefore, it is in this phase that the school has a fundamental role to play in offering healthy and nutritious foods, as these students have already acquired the ability to choose and a greater ability to buy and consume their foods (Bueno, Marchioni, Fisberg, 2003).

Despite the fact that the increase in obesity is directly related to feeding, evidence that food consumption affected the obesity rates found in this study was not found, as can be seen by the $p$-values reported in Table III. The high rates of overweight and obesity in the population studied may be directly related not only to the quality of food consumed in each group studied, but also to the quantity.

The participation of the parents would be necessary to carry out a more complete investigation of the feeding habits of students. This approach could enable comparison of data obtained from the students and that reported by the parents, in which both the quality and the quantity of foods consumed by the children could be recorded. However, there is still no interest on the part of the schools, in integrating parents into studies carried out within their institutions, probably because of their high expectations and issues of authority with regard to the school and the routines of their children within them.

Furthermore, the factor of physical activity needs to be considered, as the students, despite showing a high consumption of energy-rich foods such as sugars and fats, may also have the habit of practicing a lot of physical activity, which leads to a balance between the consumed energetic values and total energetic expenditure (Anjos, Mendonça, 2004).
The method of food frequency applied in this study may have had an influence on these results. The fact that the students were questioned about daily consumption and number of times each food group was consumed per day may have made it difficult for the students to respond accurately. On the other hand, the majority of these children had wide access to information from the media and the Internet, including information on healthy and nutritional feeding, which may have contributed in that they could have manipulated their responses according to known information about correct feeding habits.

Studies on infant feeding inquiries present further divergence of opinion. Some authors affirm that from the age of seven, children already have the ability to report foods consumed and their quantities, although only for periods that do not exceed 1 day (Livingstone, Robson, 2000). On the other hand, other authors argue that these children are not able to report food portions and quantities in food inquiries (Lytle et al., 1993; Van Horn et al., 1993). Furthermore, the following possible sources of error may distort the information on food consumption: the interviewee's perception of what they eat, the memory of the interviewee, the fact that they are being observed, effects due to the gender and environment of the interviewer, and the interviewee's willingness to collaborate with the investigation (Witschi, 1990).

The accuracy of the perception of what the interviewee eats also influences the process of obtaining reliable data. When the person refers to what they eat, they may create an idealization of what they ate. In some situations, such as that of obesity, the recording of food consumption tends to be underestimated (Bratteby et al., 1998). This study corroborates that the evaluations of feeding habits in the infant population should entail other investigative methods, which involve participation of the school or those responsible for the child.

The data on food consumption found in this study (Figure 1) are similar to that found in recent national studies (Anjos et al., 2003; Triches, Giugliane, 2005; Conde, Monteiro, 2000). In both this study and others, a high consumption of sugars and fats was observed, i.e. foods that are very energetic, but less nutritious. The consumption of food sources of vitamins, mineral salts and substances that are considered non-nutritional but have beneficial physiological effects and low energetic value, such as vegetables, had very low rates of consumption and not one item of data was found relating to excessive consumption of these foodstuffs. However, these values were very similar for both the overweight and eutrophic groups.

A low consumption of foods such as milk and its derivatives, sources of calcium and liposoluble vitamins, 
which are fundamental for the developmental phase of these children, was also found. The other food groups including cereals, fruit, meat and beans showed very satisfactory rates of consumption, as the majority of the students reported an ideal consumption of these foods.

The data obtained in this study confirmed the need for further studies to validate a food consumption questionnaire, namely, studies that evaluate the infant population according to their intellectual ability so that reliable results about food consumption in this age range can be obtained.

The prevalence of obesity among the students was an issue of concern for the schools. In all of the institutions investigated, the rates of overweight and obese children exceeded the values recommended by WHO (WHO, 1998) (Figure 2).

In order to verify the relationship of overweight children in schools with methods of nutritional care, it was investigated whether a method of nutritional intervention was in place at the schools to prevent or treat the problem. Only schools A, B and F had some type of activity related to healthy eating. These schools offered the children some basic guidance on healthy eating in science classes. Schools A and B also supplied the students with a balanced and nutritional daily lunch, prepared within the school and adhered to a menu created by nutritionists. On the other hand, this lunch was not eaten by all the students, as not all of the parents or guardians were able to pay the monthly fee for the meals.

Results show that schools A, B and $\mathrm{F}$ had higher percentages of eutrophic students, 66, 64 and $61 \%$, respectively, with schools $\mathrm{C}, \mathrm{D}$ and $\mathrm{E}$ having percentages ranging from 52 to $59 \%$ (Figure 2). In addition, the percentage of overweight students in schools A, B and F was lower compared to the other schools. In school F, the percentage was $19 \%$ and in schools A and B it did not exceed $13 \%$, while in the other schools, it ranged from 26 to $36 \%$. The percentages found in the schools, despite being high compared to WHO recommendations (Triches, Giugliane, 2005), show that the interventions carried out by schools A, B and F can have an influence on the weight of the children.

However, with regard to obesity, the lowest rates were observed in schools $\mathrm{C}$ and $\mathrm{D}(12 \%)$, followed by schools B and E (13\%), A (14\%) and F (16\%) (Figure 2). This supports the affirmations of various authors (Anjos, Mendonça, 2004; Muller et al., 2001) who state that it is unlikely that isolated actions of intervention, such as those carried out in schools A, B and F, will resolve the problem of obesity, as they do not affect all the students. A combination of activities that serve the needs of all of the children, awakening their interest and conscience about healthy life habits, is necessary. Fernandes et al. (2009) as- sessed the effects of a nutritional education program on the prevalence of overweight/obesity and on the foods eaten by schoolchildren in the 2 nd grade of primary education. The program consisted of eight fortnightly meetings and covered subjects related to healthy diets, how to make healthy snacks, and physical activity. After attending the nutritional education program, there were improvements in the quality of the food the schoolchildren were eating.

This study corroborates other national studies and draws attention to the high rate of obesity found among the infant population. Obesity is currently a serious public health problem in Brazil and the world, and it is necessary to raise awareness of the problem in order to combat the disease and increase the credibility of nutritional education by carrying out more studies confirming the efficiency of this approach within educational institutions. To lower risk factors for diseases, the fight against excess weight within schools should include individual and group actions that embrace all students.

The act of feeding oneself comprises a wide range of human behavior and is not limited to a single mechanical and measurable variable. The understanding of the nutritional profile of the population cannot be reduced, therefore, to anthropometric variables. Obesity does not represent a simple question of positive energetic balance (Carvalho, Martins, 2004). Therefore, health professionals, when suggesting any intervention in the area of feeding, should not focus on the isolated interventions of changes in feeding habits, but also consider the cultural aspects involved, including the influence of parents, classmates, health publicity and self-image, in the development of educational activities (Ramalho, Saunders, 2000). Stringheta et al. (2007) presented the National Feeding and Nutrition Policies directives and emphasized that these directives focus on the reduction of non-transmissible chronic diseases among the public by means of healthy feeding and physical activity.

The data obtained in this study confirms the need to implement in schools, beyond nutritious lunches, nutritional education actions connected to activities promoting health. These activities should be used as support material in the promotion of appropriate feeding habits and health, and the schools need to be conscious of the need for interaction between themselves, the students and their parents. Nutritional education is a measure that can and should be initiated at pre-school level and extended to higher levels. The opportunities offered by the various parts of the curriculum should be exploited, interspersing theories about nutrition with horticultural, culinary and tasting activities through school lunches (Souza, Vilas Boas, 2004). Educational interventions, therefore, should 
be an integral part of education, enabling school children to gain access to knowledge about food and thus attain a state of ideal health.

\section{ACKNOWLEDGEMENTS}

The authors wish to thank the Coordenação de Aperfeiçoamento de Pessoal de Nível Superior (CAPES) for the post-graduate grant used to carry out this research.

\section{REFERENCES}

ANJOS, L.A.; CASTRO, I.R.R.; ENGSTRON, E.M.; AZEVEDO, A.M.F. Crescimento e estado nutricional em amostra probabilística de escolares no Município do Rio de Janeiro. Cad. Saúde Pública, v.19, suppl.1, p.171-179, 2003.

ANJOS, L.A.; MENDONÇA, C.P. Aspectos das práticas alimentares e da atividade física como determinantes do crescimento do sobrepeso/obesidade no Brasil. Cad. Saúde Pública, v.20, p.698-709, 2004.

BRATTEBY, L.E.; SANDHAGEN, B.; FAN, H.; ENGHARD, H.; SAMUELSON, G. Total energy expenditure and physical activity as assessed by doubly labeled water method in Swedish adolescents in whom energy intake was underestimated by 7 day diet records. Am. J. Clin. Nutr., v.67, p.905-911, 1998.

BUENO, M.B.; MARCHIONI, D.M.L.; FISBERG, R.M. Evolução nutricional de crianças atendidas em creches públicas no município de São Paulo. Rev. Panam. Salud Pública, v.14, p.165-168, 2003.

CARVALHO, M.C.; MARTINS, A. A obesidade como objeto complexo: uma abordagem filosófico-conceitual. Ciênc. Saúde Coletiva, v.9, p.3-12, 2004.

CONDE, W.L.; MONTEIRO, C.A. Tendência secular da desnutrição e da obesidade na infância da cidade de São Paulo. Rev. Saúde Pública, v.34, p.52-61, 2000.

CORSO, A.C.T.; BOTELHO, L.J.; ZENI, L.A.Z.R; MOREIRA, E.A.M. Sobrepeso em crianças menores de 6 anos de idade em Florianópolis. SC. Rev. Nut., v.14, p.21-32, 2001.

CRUZ, A.T.; PHILLIPPI, S.T. Pirâmide alimentar para crianças de 2 a 3 Anos. Rev. Nutr., v.16, p.5-19, 2003.
FERNANDES, P.S.; BERNARDO, C.O.; CAMPOS, R.M.M.B.; VASCONCELOS, F.A.G. Avaliação do efeito da educação nutricional na prevalência de sobrepeso/obesidade e no consumo alimentar de escolares do ensino fundamental. $J$. Pediatr., v.85, p.315-321, 2009.

GOUVEIA, A. Nutrição e comunidade. São Paulo: Atheneu, 1999. $247 \mathrm{p}$.

JELLIFFE, D.B. Evaluación del estado de nutrición de la comunidad. Ginebra: Organización Mundial de la Salud, 1968. $291 \mathrm{p}$.

LIVINGSTONE, M.B.; ROBSON, P.J. Measurement of dietary intake in children. Proc. Nut. Soc., v.59, p.279-293, 2000.

LYTLE, L.A.; NICHAMAN, M.Z.; OBARZANEK, E.; GLOVSKY, E.; MONTGOMERY, D.; NICKLAS, T.; ZIVE, M.; FELDMAN, H. Validation of 24-hour recall assisted by food records in third-grade children. J. Am. Diet. Assoc., v.93, p.1431-1436, 1993.

MATHEWS, A.E. Children and obesity: a pan-European project examining the role of food marketing. Eur. J. Publ. Health, v.18, p.7-11, 2007.

MENDES, M.J.F.L.; ALVES, J.G.B.; ALVES, A.V.; SIQUEIRA, P.P.; FREIRE, E.F.C. Associação de fatores de risco para doenças cardiovasculares em adolescentes e seus pais. Rev. Bras. de Saúde Matern. Infant., v.6, suppl.1, p.49-54, 2006.

MODESTO, S.P.; DEVINCENZI, M.U.; SIGULEM, D.M. Práticas alimentares e estado nutricional de crianças no segundo semestre de vida atendidas na rede pública de saúde. Rev. Nutr., v.20, p.405-15, 2007.

MONDINI, L.; LEVY, R.B., SALDIVA, S.R.D.M.; VENANCIO, S.I.; AGUIAR, J.A.; STEFANINI, M.L.R. Prevalência de sobrepeso e fatores associados em crianças ingressantes no ensino fundamental em um município da região metropolitana de São Paulo, Brasil. Cad. Saúde Pública, v.23, p.1825-1834, 2007.

MULLER, M.J.; MAST, M.; ASBECK, I.; LANGNASE, K.; GRUND, A. Prevention of obesity - it is possible? Obes. Rev., v.2, p.15-28, 2001.

MUST, A.; DALLEL, G.E.; DIETZ, W.H. Reference data for obesity: $85^{\text {th }}$ and $95^{\text {th }}$ percentiles of Body Mass Index (wt/ ht2) and triceps skin fold thickness. Am. J. Nutr., v.53, p.839-846, 1991. 
RAMALHO, R.A.; SAUNDERS, C. O papel da educação nutricional no combate às carências nutricionais. Rev. Nutr., v.13, p.11-16, 2000.

RICARDO, G.D.; CALDEIRA, G.V.; CORSO, A.C.T. Prevalência de sobrepeso e obesidade e indicadores de adiposidade central em escolares de Santa Catarina, Brasil. Rev. Bras. Epidemiol., v.12, p.424-35, 2009.

ROCCA, S.V.S.; TIRAPEGUI, J.; MELO, C.M.; RIBEIRO, S.M.R. Efeito do exercício físico nos fatores de risco de doenças crônicas em mulheres obesas. Rev. Bras. Cienc. Farm., v.44, p.185-192, 2008.

ROTTEMBERG, S.; VARGAS, S. Práticas Alimentares e o Cuidado da Saúde: da Alimentação da Criança à Alimentação da Família. Rev. Brás. Saúde Matern. Infant., v.4, p.85-94, 2004.

SILVA, G.A.P.; BALABAN, G.; MOTTA, M.E.F. Prevalência de sobrepeso e obesidade em crianças e adolescentes de diferentes condições socioeconômicas. Rev. Brás. Saúde Matern. Infant., v.5, p.53-59, 2005.

SILVA, M.V.; OMETTO, A.N.H.; FURTuOsO, M.C.O.; PIPITONE, M.A.P.; STURION, G.L. Acesso à creche e estado nutricional das crianças brasileiras: diferenças regionais, por faixa etária e classes de renda. Rev. Nutr., v.13, p.193-199, 2000.

SOTELO, Y.O.M.; COLUGNATI, F.A.B.; TADDEI, J.A.A.C. Prevalência de sobrepeso e obesidade entre escolares da rede pública segundo três critérios de diagnóstico antropométrico. Cad. Saúde Pública, v.20, p.233-240, 2004.

SOUZA, W.A.; VILAS BOAS, O.M.G.C. Orientação sobre o uso de vitamina A na saúde escolar: comparação de técnicas pedagógicas. Ciênc. Saúde Coletiva, v.9, p.183-190, 2004.
STRINGHETA, P.C.; OLIVEIRA, T.T.; GOMES, R.C.; AMARAL, M.P.H.; CARVALHO, A.F.; VILELA, M.A.P. Políticas de saúde e alegações de propriedades funcionais e de saúde para alimentos no Brasil. Rev. Bras. Cienc. Farm., v.43, p.181-194, 2007.

TRICHES, R.M.; GIUGLIANE, E.R.J. Obesidade, práticas alimentares e conhecimentos de nutrição em escolares. Rev. Saúde Pública, v.39, p.541-547, 2005.

VAN HORN, L.V.; STUMBO, P.; MOAG-STAHLBERG, A.; OBARZANEK, E.; HARTMULLER, V.W.; FARRIS, R.P.; KIMM, S.Y.; FREDERICK, M.; SNETSELAAR, L.; LUI, K. The dietary intervention study in children (DISC): dietary assessment methods for 8- to 10-year-olds. J. Am. Diet. Assoc., v.93, p.1396-1403, 1993.

WILLETT, W.C. Future directions in the development of foodfrequency questionnaires. Am. J. Clin. Nutr., v.59, suppl.1, p.171-174, 1994.

WITSCHI, J.C. Short-term dietary recall and recording methods. In: Willet, W. Nutritional epidemiology. New York: Oxford University Press, 1990. p. 52-68.

WORLD HEALTH ORGANIZATION. Obesity: preventing and managing the global epidemic. Report of a WHO consultation of obesity. Geneva, 1998. Available at: <www. nutritionsociety.org/documents/20051116reading3Clin. pdf. $>$. Accessed on: 08 set. 2008.

Received for publication on $10^{\text {th }}$ December 2009 Accepted for publication on $02^{\text {nd }}$ March 2010 